\author{
Jaroslav David \\ Ostravská univerzita, Ostrava
}

\title{
Mikrotoponymie městského prostoru
}

\section{Zkoumané lokality - socialistická města}

V prostoru střední Evropy vznikla v období 2. poloviny 40. let a v 50. letech 20. století řada nových měst a sídlišst', jež byla vybudována na „zelené louce“. Jednalo se o lokality, které byly vystavěny nejen z praktických potřeb jako obytné zóny v průmyslových oblastech, ale také jako nová socialistická města, reprezentující novou etapu vývoje společnosti. Uvedený typ měst představují např. Stalinstadt (dnes Eisenhüttenstadt) na území bývalé NDR, Nowa Huta u Krakówa v Polsku nebo Sztálinváros (dnes Dunaújváros) v Mad'arsku. Rovněž na území bývalého Československa najdeme několik př́kladů budovatelských měst, koncipovaných pro „nového“, socialistického člověka. Náleží k nim např. Nová Dubnica u Dubnice nad Váhom, Ostrov nad Ohří, sídliště Stalingrad (Ostrava-Zábřeh), Březové Hory (Př́bram) a především dvě lokality, jimž budeme věnovat pozornost v našem textu, Ostrava-Poruba a Haviřov. Obě místa spojuje doba vzniku, ale také region. Nacházejí se v dnešním Moravskoslezském kraji, v oblasti v 50. letech považované za „průmyslové srdce republiky“, kde byl soustředěn průmysl uhlí a železa.

Ostravská Poruba, v projektech označovaná Nová Ostrava, byla zamýšlena jako nové město, které mělo nahradit „starou“ Ostravu, znečištěnou těžkým průmyslem a určenou $\mathrm{k}$ demolici $\mathrm{z}$ důvodu těžby uhlí. Nové sídliště Poruba vzniklo západně od centra Ostravy na území stejnojmenné venkovské obce, jak ukazuje i porovnání dvou map, indikační skici stabilního katastru z roku 1836 a plánu města Ostravy z roku 1964 (viz Obrázek 1 a 2; vyznačený bod označuje tutéž polohu). Výstavba sídliště začala na počátku 50 . let na zemědělských pozemcích severně od původní obce.

Osudy vzniku Havírovova byly složitější. Na katastrech vesnic Šenov, Šumbark, Dolní Bludovice a Prostřední Suchá byla již ve 40. letech rozptýlená zástavba obytných domů s centrem na území obce Šumbark. Růst počtu obyvatel i administrativní potřeby si vyžádaly vytvoření nového města, které bylo vyhlášeno 


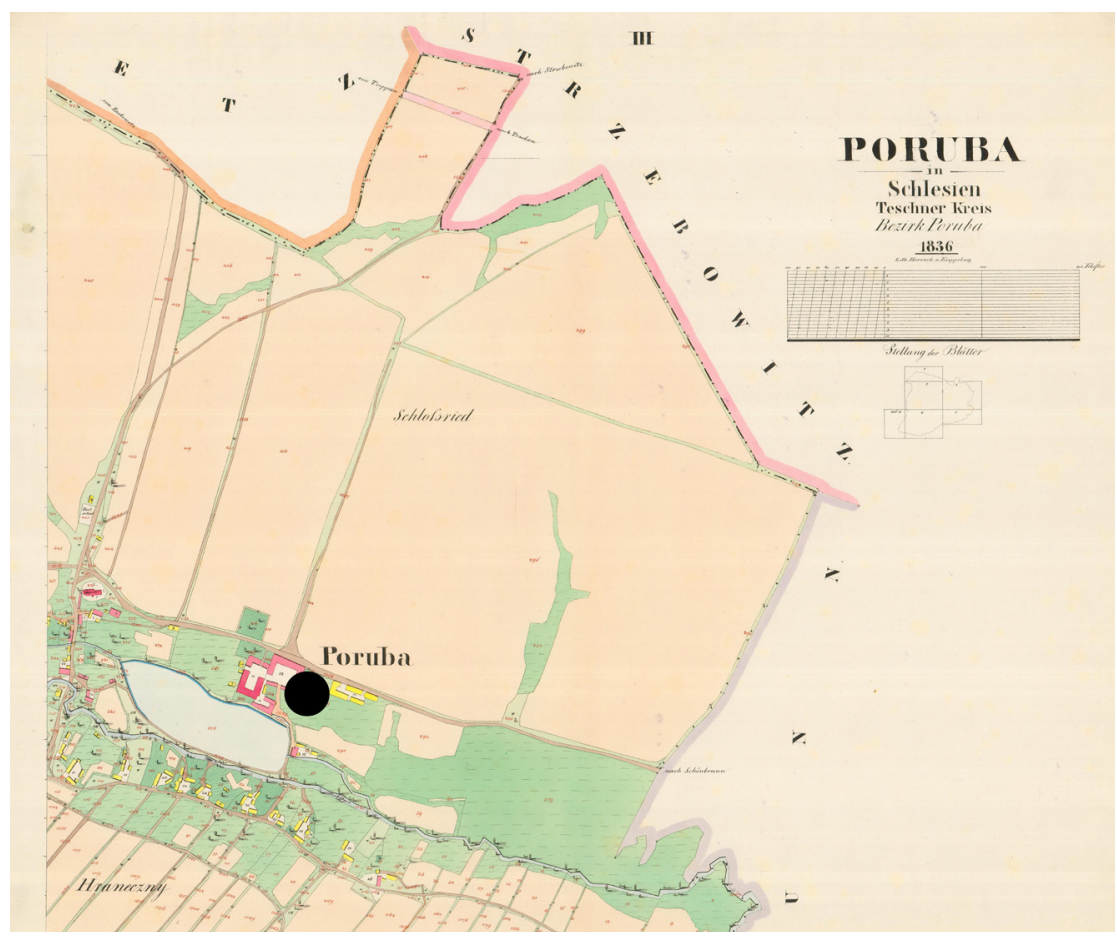

Obrázek 1.

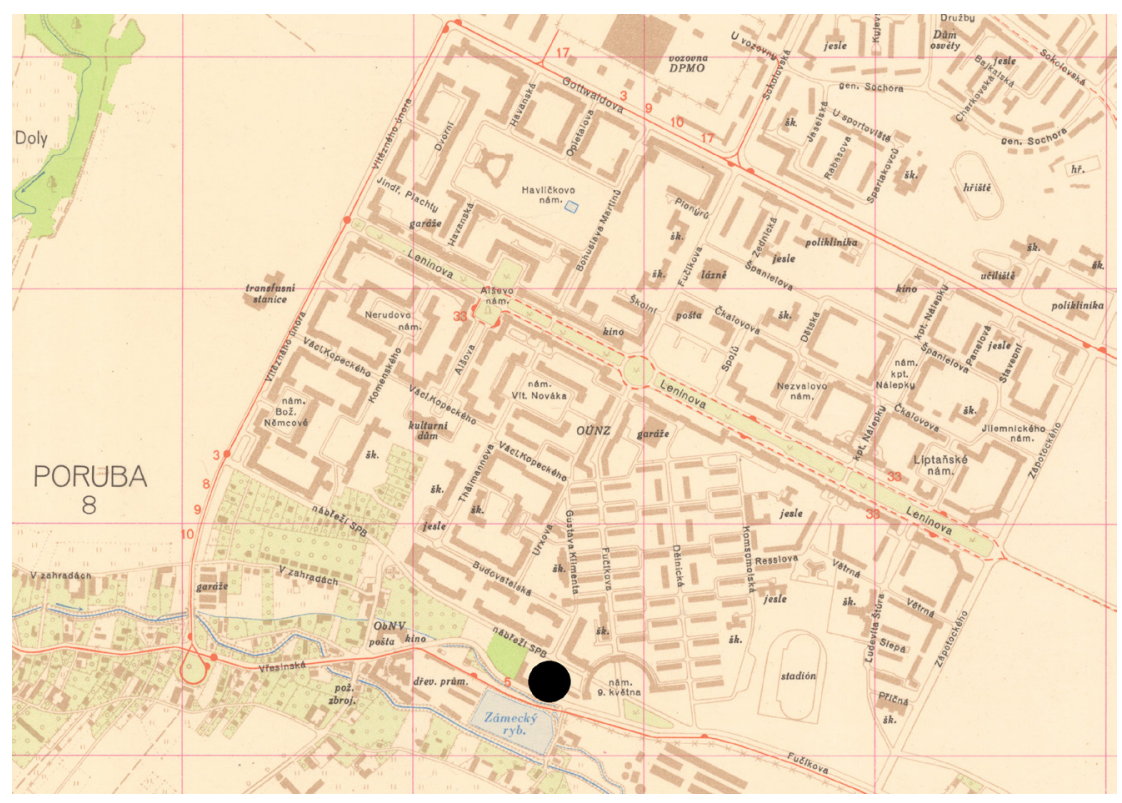

Obrázek 2. 
v prosinci 1955 a dostalo čestný název Haviřov [k soutěži na název města viz David 2011: 134-154]. Osou nového města se stala bývalá císařská silnice spojující Ostravu s Těšínem, jak dokládá porovnání dobových map, mapy stabilního katastru z roku 1836 a plánu města z roku 1987 (viz Obrázek 3 a 4).

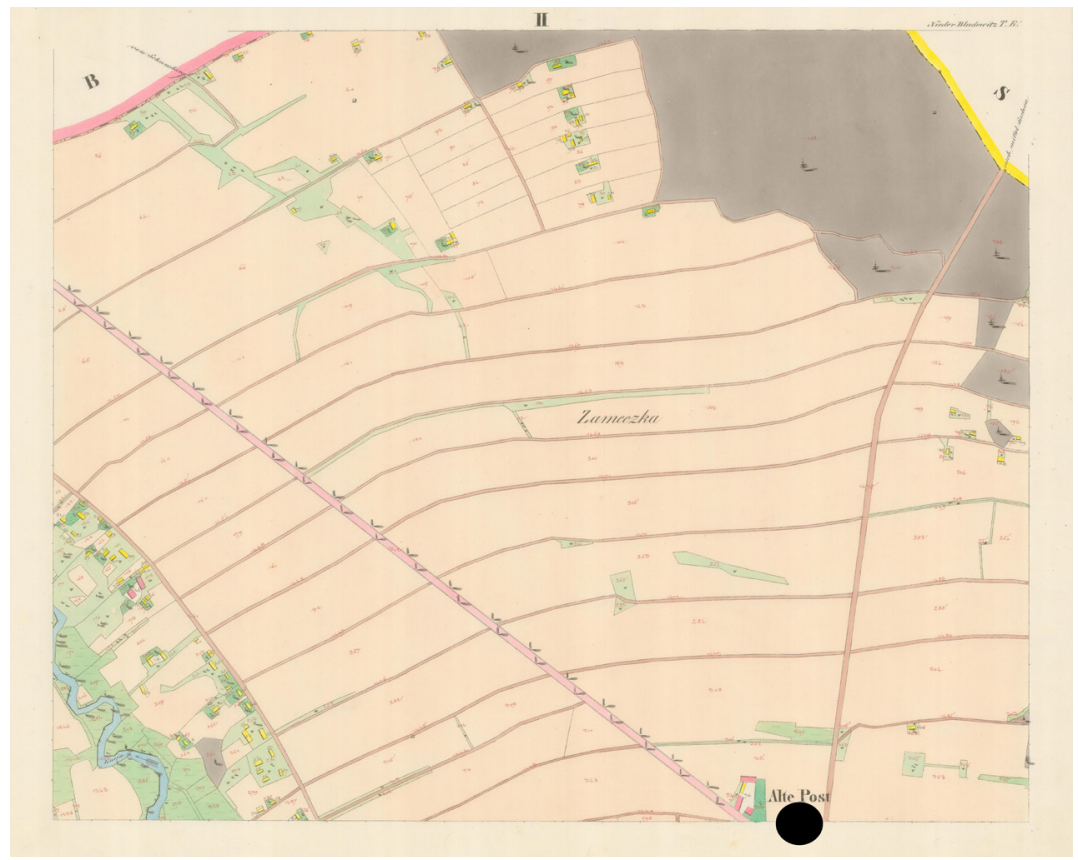

Obrázek 3.

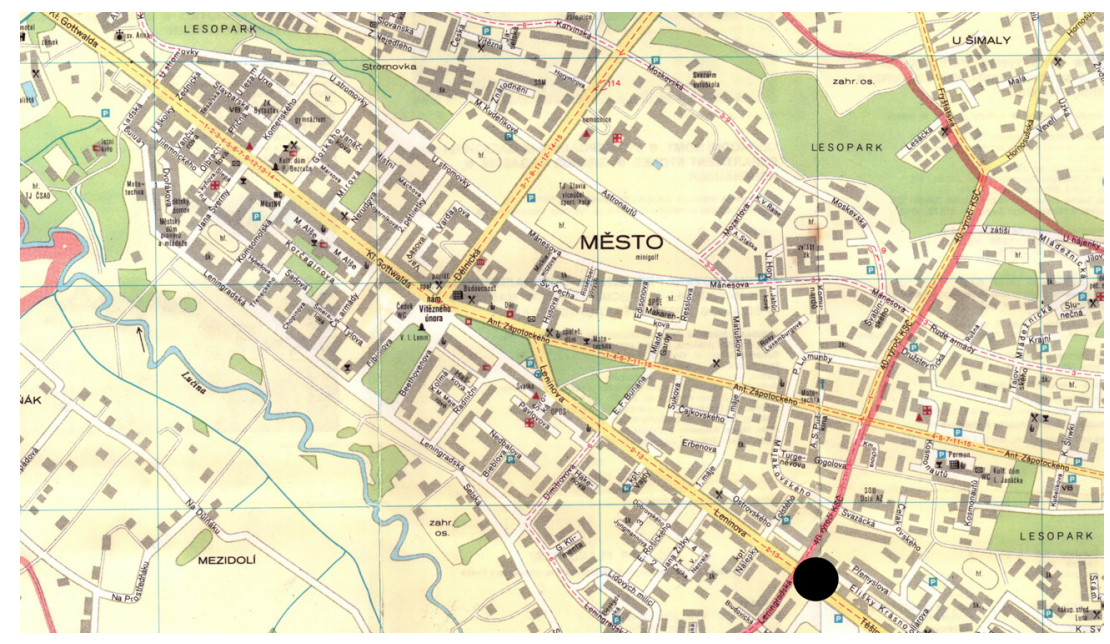

Obrázek 4. 


\section{Standardizovaná urbanonymie}

Obě lokality, ostravská Poruba i město Havířov, mají mnoho společných rysů. Poruba i Havířov byly vybudovány na katastrech původně venkovských obcí jako vzorová socialistická města pro obyvatelstvo, které přicházelo do regionu za prací z různých míst Československa. Pro orientaci v nich zpočátku sloužila pouze čísla bloků obytných domů, teprve později zde byla zavedena uliční jména. Urbanonymie center sledovaných měst, tedy nejstarších obvodů podél hlavní třídy, byla v době jejich vzniku tvořena téměř $100 \%$ honorifikačními názvy typu Leninova tř́da (dnes Hlavni trída), Gottwaldova tř́da (Opavská), Zápotockého (Francouzská, Ostrava-Poruba); Klementa Gottwalda (dnes Hlavni tř́da), Leninova (Národni tř́da), Antonína Zápotockého (Dlouhá tř́da, Havírov) [viz též David 2011: 178, 182-183; David, Mácha 2014: 88-90]. Urbanonymie nového města tedy vůbec nenavazovala na původní pomístní jména venkovského katastru, ani neobsahovala popisné či charakterizační názvy. Nejen honorifikační, především deantroponymická toponyma, k prostoru zcela indiferentní, ale i fakt vysoké migrace obyvatelstva vytvářely podmínky pro prostorovou „nezakořeněnost“" obyvatel města. Jsme svědky toho, jak v této „laboratoři“, kde měl být zformován „nový““ člověk, vzniká také nová, nestandardizovaná toponymie [k tématu nestandardizované městské toponymie historických malých měst srovnej též Ireinová, 2010; Ireinová, Konečná 2010; David 2012c].

Významnou roli při vzniku nestandardizované, „živé“ toponymie sehrál především podobný urbanismus obou měst. Jeho páteří se stala hlavní tř́da obklopená obytnými bloky; jeho výraz určovala dekorativně-monumentální architektura tzv. stalinské renesance (arch. Boris Jelčaninov a arch. Vladimír Meduna), která pracovala s pohledovými dominantami, napřr. věžemi a průjezdy [Strakoš 2010: 150-181].

\section{Nestandardizovaná (,živác) urbanonymie}

V rámci výzkumného projektu zaměřeného na městskou toponymii, standardizovanou i nestandardizovanou, a na její úlohu při vytváření prostoru a identity obyvatel poválečných měst a sídlišt', v komparaci s venkovskými lokalitami, jsme se zaměřili na př́islušníky nejstarší generace porubských a havířovských obyvatel, ve věku nad 60 let [David, Mácha 2014]. V této skupině jsme formou řízených rozhovorů (12) a dotazníků (40) zjišt’ovali, jaká „živá“ pojmenování obyvatelé užívají pro místa ve městě, která vznikla a existovala v období 50.-70. let 20 . století. Problémem, s nímž jsme se museli vypořádat při sběru materiálu, byl fakt vymezení „živého“ toponyma, respektive sociálního mikrotoponyma. Kritériem pro jeho stanovení byla onymická funkčnost a opakovaný výskyt toponyma [k problému viz např. Krško 1998: 115; nejnověji Krško 2013; David, Mácha 
2014: 18-23]. Nestandardizovaná toponymie se také vyznačuje vícevrstevnatostí. Pro jeden objekt uváděli respondenti jednotlivých generací odlišné názvy, ale také používali jeden název s různým plošným rozsahem zahrnující více lokalit označených samostatnými toponymy [k problému vymezení toponyma srovnej např. Harvalík 2001; Pleskalová 1978; Šrámek 1980].

V obou lokalitách se projevily nápadné shody „živé“ toponymie, dané právě architekturou a prostorovým členěním měst. Kromě používání názvů obvodů, např. Trojka / Na Trojce (Haviŕřov-Šumbark); Jednička, Čtyřka (Ostrava-Poruba), to byly totožné orientační body vyskytující se v názvech. V Havířově i Porubě jsme zachytili pojmenování Rondl / U Rondlu (kruhový objezd, rondel), Nábřě̌í, Kravín (dlouhá nízká bílá budova připomínající kravín), Labužník / U Labužnika (obchod s potravinami a cukrárna Labužník). Obě města byla v místech, kde stará zástavba 50. let navazovala na modernější část 60 . let, osazena sochou V. I. Lenina, proto i název U Lenina (Havířov, dnešní náměstí Republiky) a Leninka (komunikační varianta názvu Leninova tř́da, Ostrava-Poruba). Pro centra obou měst se orientačními body staly rovněž školy, v Havířově především budovy hornických učilišt' A-zet (učiliště Antonína Zápotockého) a Korčagin (učiliště Pavky Korčagina), v Porubě budovy škol Malá a Velká Thälmannka.

Analýza rozhovorů a materiálu získaného dotazníkovým výzkumem ukázala, že ,živá“ toponymie, sledovaná na př́kladu dvou podobně koncipovaných měst, je velmi výrazně určována jejich urbanismem a architekturou. Promítá se do ní nejen rozvržení prostoru, např. Nábřeží, U Rondlu, U Lenina, ale také specifické dekorativní prvky architektury sorely (socialistického realismu), např. Oblouk / U Oblouku, Věžičky, Podloubí.

Ze současného pohledu můžeme také konstatovat, že tato původně nestandardizovaná toponymie proniká i do oficiálních textů, napřs. inzeráty a reklamy, oznámení o konání akcí, a dokonce se stává součástí standardizované toponymie, urbanonymie. V Ostravě-Porubě se pojmenování Věžičky a Oblouk stala názvy zastávek městské hromadné dopravy, v Havířově najdeme zastávku Podloubí. Porubské náměstí 9. května bylo v říjnu 1992 př̀menováno na $U$ Oblouku.

Náš výzkum rovněž potvrzuje fakt, a to při porovnání výsledků získaných u různých věkových skupin obyvatel, že znalost nestandardizované toponymie je vázána generačně a s generacemi se proměňuje i zaniká [srovnej David 2012a; David 2012b; David, Mácha 2014]. Tuto skutečnost dobře ilustrují jak př́íklady z Havírova, tak z ostravské Poruby. Havírovské náměstí Vítězného února (dnes náměstí Republiky) bylo označováno jako U Lenina, a tak je znají př́slušníci nejstarší generace (viz Obrázek 5 a 6). Po odstranění Leninovy sochy a umístění skulptury Kyvadlo je náměstí označováno jako $U$ Kyvadla, popř. ironicky $U$ Gilotiny, nebo jen prostě Namko. Uvedené názvy používají především př́slušníci nejmladší generace, jak ukázal náš výzkum na havířovských základních a středních školách. Ještě zajímavější příklad generačních proměn toponyma můžeme uvést z Poruby. Budova dnešního Wichterlova gymnázia je pro př́slušníky nejstarší 


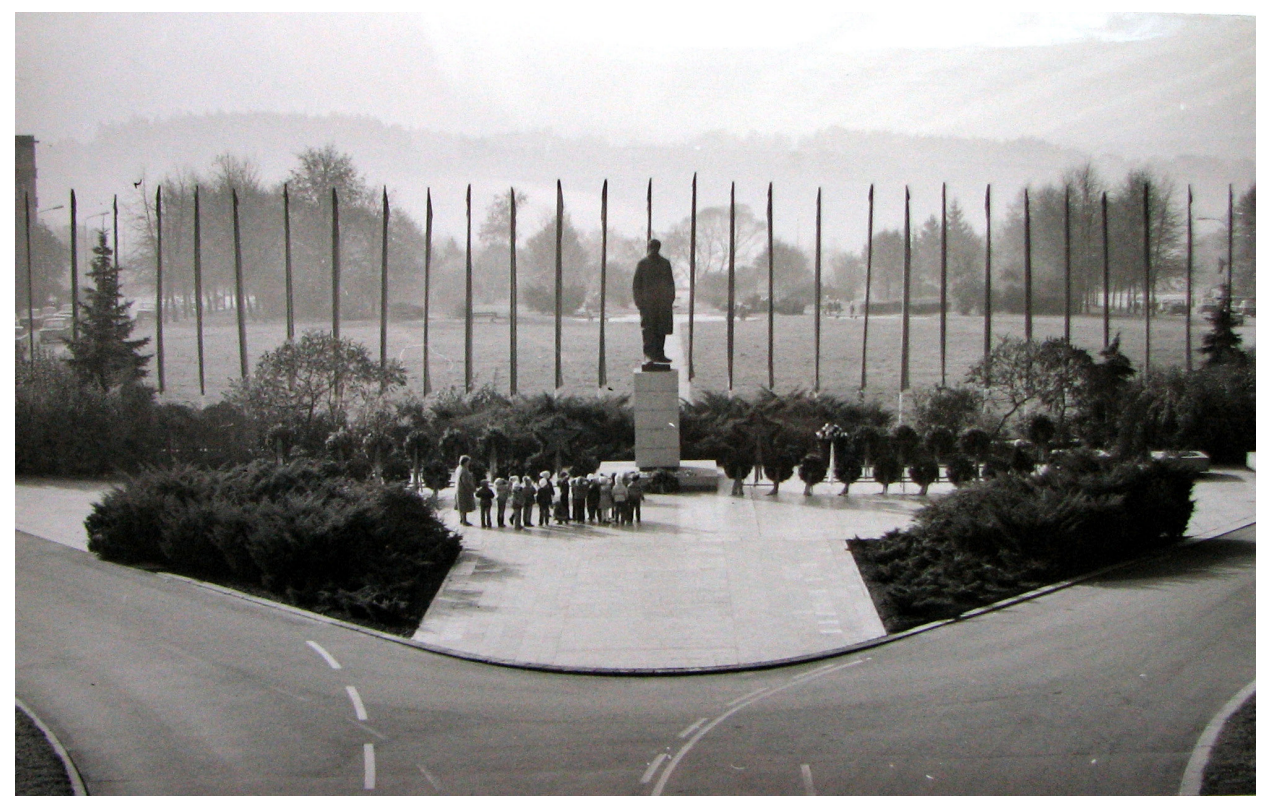

Obrázek 5.

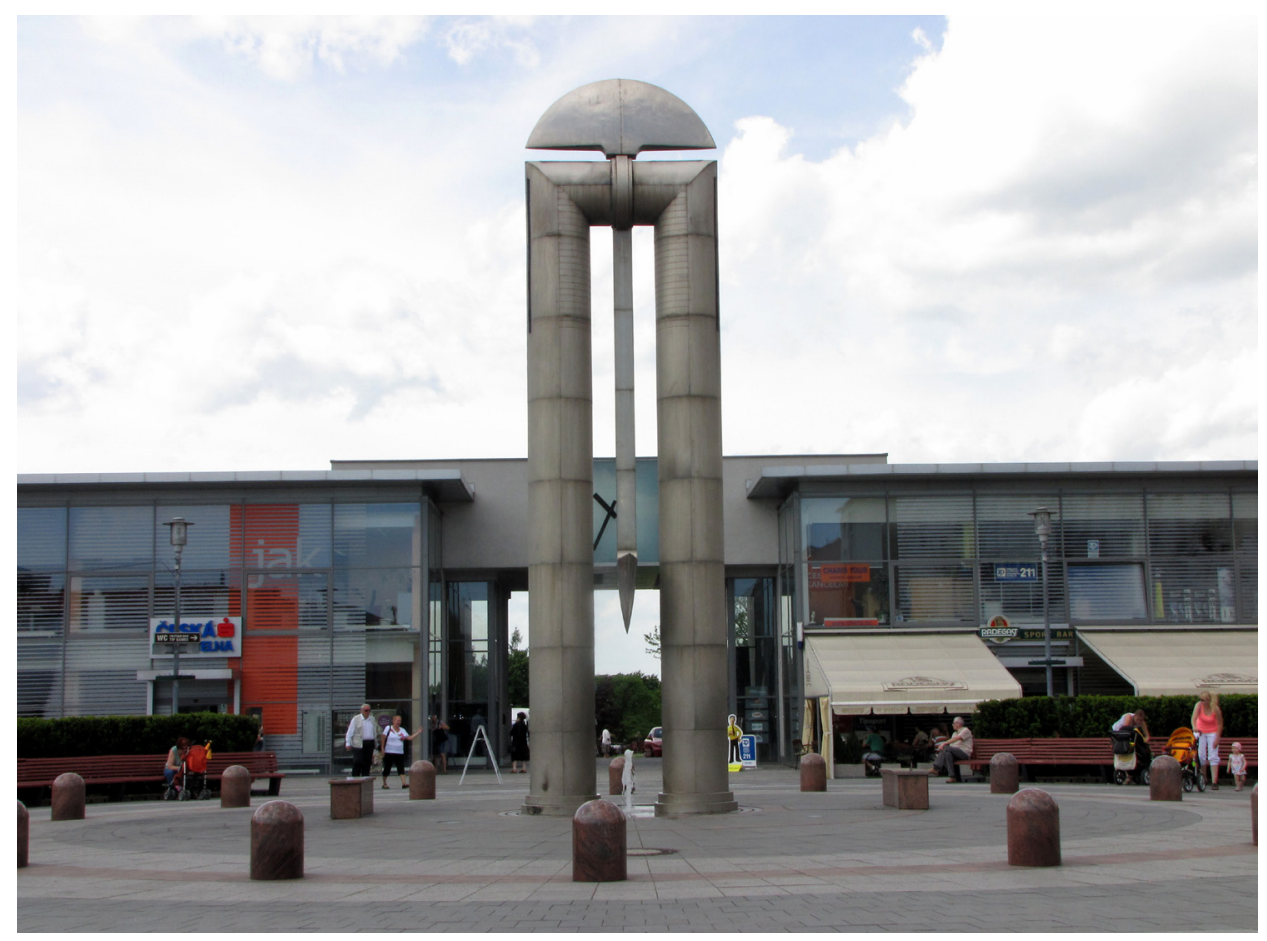

Obrázek 6. 
generace obyvatel Velká Thälmannka, dle Thälmannovy ulice, později po roce 1990 přejmenované na ulici Čs. exilu, Velký Exil; jako Malá Thälmannka je označováno nedaleké Gymnázium Pavla Tigrida.

Při sběru materiálu v Haviŕově jsme zaznamenali rovněž toponymický folklor. Kromě ironického názvu Blátošlapy (označení města $\mathrm{v}$ době jeho budování na rozbahněných polích), to bylo pojmenování Korea, používané od 50. let 20. století a dnes již téměř zapomenuté, pro nejstarší část, sídliště Šumbark. Název Korea vznikl metaforickým přenesením, a to na základě podobnosti rozestavěného sídliště $\mathrm{s}$ válečným bojištěm $\mathrm{v}$ Koreji, aktuálním tématem dobové publicistiky. Tři respondenti uvedli v rozhovoru také úsloví komentující prostorovou situaci, kdy Leninova socha byla otočena směrem k obchodnímu domu Budoucnost (dnes Elan) a do Dělnické tř́dy: Lenin se divá do budoucnosti a na dělnickou tř́du. Srovnej též přepis nahrávky části jednoho rozhovoru (Haviŕrov, respondenti 67 a 70 let): „Na náměstí - Budoucnost je dneska Elan. Tomu se ř́íkalo 'do Budky'. Pak jsem šel s dětmi do parku, za dnešní spořitelnou, to bylo ' $\mathrm{k}$ Leninovi'. Tam stál a díval se směrem na Budoucnost, vždycky jsme se smáli: Ano, budeme se mít dobře. [...] Aurora. Ano. To v zimě obyčejně unikala teplá voda a v prostředním pásu, $v$ tom zeleném, byl poklop a z toho unikala pára. Tak jsme říkali: Půjdeme se podívat na Auroru, pokaždé to bylo jiné, jednou více, jindy méně. To bylo spojené všechno dohromady, náměstí Vítězného února, stál tam Lenin, hleděl do Budoucnosti a mezi nimi byla Aurora“.

\section{Závěr}

Výzkum a srovnání „živé“ toponymie obou sledovaných lokalit, Ostravy-Poruby a Havířova, upozornily na zásadní roli uspořádání městského prostoru pro vytváření nestandardizovaných jmen, a to na pozadí dobové honorifikační standardizované toponymie. Výsledky analýzy toponymického materiálu zdůraznily téma generačního zakotvení mikrotoponymie a jejích proměn v čase.

Příspěvek vznikl s podporou výzkumného projektu Programu aplikovaného výzkumu a vývoje národní a kulturní identity (NAKI) č. DF11P01OVV022 Mistni a pomistní názvy jako kulturní dědictví a zdroj lokální, regionální a národní identity. Připrava metodiky ochrany mistních a pomístních jmen (www stránky projektu: http://projekty.osu. cz/mistapameti/; http://www.nazvymist.cz/) [dostęp 30.09.2012].

\section{Bibliografie}

David Jaroslav, 2011, Smrdov, Brežněves a Rychlonožkova ulice. Kapitoly z moderní české toponymie, Praha.

David Jaroslav, 2012a, Pamět města - názvy mist HAVÍŘOV, Ostrava.

David Jaroslav, 2012b, Pamět' města - názvy mist OSTRAVA, Ostrava. 
David Jaroslav, 2012c, Toponyma a orientace v současném městském prostoru aneb Ztracen ve městě, [in:] Martin Ološtiak (ed.), Jednotlivé a všeobecné v onomastike. 18. slovenská onomastická konferencia. Prešov 12.-14. septembra 2011, Prešov, 229-236.

David Jaroslav, Mácha Přemysl, 2014, Názvy mist. Pamět', identita, kulturní dědictví, Brno.

Harvalík Milan, 2001, Poznámky ke vztahům mezi anoikonymy a apelativní slovní zásobou, „Jazykovědné aktuality“ 38, č. 3, 25-33.

Ireinová Martina, 2010, Znalost pomístnich jmen v Rosicích, „Acta onomastica“ 51, č. 1, 247-268.

Ireinová Martina, Konečná Hana, 2010, Konfrontace znalosti pomistnich jmen v Jemnici, Rosicích a Lhoticích, „Acta onomastica“ 51, č. 1, 299-313.

Krško Jaromír, 1998, Mikrosociálne mikrotoponymá, [in:] Milan Majtán, Pavol Žigo (eds.), 13. slovenská onomastická konferencia, Modra-Piesok, 2.-4. októbra 1997, Bratislava, 115-119.

Krško Jaromír, 2013, Toponymický priestor ako súčast' kultúrno-antropologického priestoru, „Acta onomastica" $54,151-169$.

Pleskalová Jana, 1978, K hranici mezi apelativy a proprii (na materiálu pomístních jmen), „Zpravodaj Místopisné komise ČSAV“ 19, 296-300.

Strakoš Martin, 2010, Nová Ostrava a její satelity. Kapitoly z dějin architektury 30.-50. let 20. století, Ostrava.

Šrámek Rudolf, 1980, Pomístni jména typu “Za lesem, Na nivě”, „Zpravodaj Místopisné komise ČSAV“ 21, 638-650.

\section{Jaroslav David}

\section{Microtoponymy of urban area}

(Summary)

This text presents a research focused on non-standardized toponymy used in the urban areas of the new Czech socialist towns of Ostrava-Poruba and Havírov. These towns were founded after the Second World War as housing estates for workers in heavy industry and coal mines. The towns were built according to a similar plan in the same decorative style of architecture known as "Sorela", an abbreviation of the Socialist Realism collocation, with a prevalence of commemorative street names typical of the era. The spatial similarity of the two towns determined the similarity of non-standardized toponymy, used in parallel with official street and square names. This fact is illustrated by the oldest layer of non-standardized place names used by the towns' inhabitants, in comparison with the youngest generation of their inhabitants.

Słowa kluczowe: mikrotoponimia, urbanonimia, urbanonimia nieustalona (niestandardyzowana), czeskie miasta socjalistyczne.

Key words: microtoponymy, urbanonymy, non-standardized urban place names, Czech socialist cities. 


\section{Armina Muszyńska}

Uniwersytet Łódzki

\section{Plateonimy i agoronimy centralnej przestrzeni Suboticy (Serbia) jako świadectwo wielokulturowości miasta}

\section{Wprowadzenie}

Szata informacyjna miasta stanowi przedmiot zainteresowania wielu dyscyplin, w tym geografów, którzy doszukują się relacji zachodzących między nimi w przestrzeni, a także z przestrzenią społeczną miast. Hodonimy pełnią zróżnicowane funkcje: orientacyjną, lokalizacyjną, symboliczną [Balowski 2010: 283]. Zajmująca wydaje się szczególnie ta ostatnia, która przyczynia się do propagowania społecznie akceptowanych wartości oraz wskazuje na system wartości danej społeczności [Balowski 2010: 283]. Zastanawiające jest, czy w tym kontekście nazewnictwo miejskie może stanowić szatę ideologiczną i odzwierciedlać strukturę narodowościową i wielokulturowość miasta poprzez odniesienia nazw do kultur danych narodów. W celu odpowiedzi na to pytanie, wybrane urbotoponimy uznane zostały za znaki, poprzez które dokonywana jest stygmatyzacja miasta przez jego mieszkańców lub władze, czy, jak ujmuje to Handke, „opanowanie środowiska i podporządkowanie go zasadom funkcjonowania wspólnoty mieszkańców" [Handke 2010: 360]. Za podmiot analizy obrano centrum położonego w Serbii miasta Subotica, które wyróżnia wielokulturowość potwierdzona zarówno przez dane statystyczne, jak i elementy materialne w przestrzeni: świątynie, cmentarze, pomniki, a także urbotoponimy, o których językoznawca z Serbii, Laćević [1984: 217] napisała: „Nazwy ulic bowiem są [...] specyficznymi pomnikami kultury, które świadczą o życiu danej osady i jej przeszłości”. O wyborze Suboticy przesądził również brak konfliktów na tle etnicznym od II wojny światowej. Nasuwa się pytanie, czy harmonia istniejąca między nacjami zamieszkującymi miasto widoczna jest w nazwach ulic, placów, parków, a także czy istnieje związek między zróżnicowaniem narodowościowym w wybranych dzielnicach miasta a występującymi tam hodonimami. Procedura badawcza składała się z kilku etapów. Pierwszym było zapoznanie się z historią miasta, w szczególności z wydarzeniami przyczyniającymi się do zmian z strukturze demograficznej. Kolejnym 
było opracowanie i przeprowadzenie geograficznej metody analizy problemu oraz ocena jej przydatności do dalszych badań.

W artykule zastosowano serbską wersję onimów, zapisując je łacinką i wyróżniając kursywą. Cytaty z literatury serbskiej, chorwackiej i buniewskiej podano w thumaczeniu autorki.

\section{Subotica - rys historyczny}

Subotica położona jest w północnej części Serbii, w Prowincji Autonomicznej Wojwodinie, kilkanaście kilometrów od granicy z Węgrami. Położenie geograficzne - w żyznej i równinnej krainie zwanej Baczką, sprawiło, że miasto rozwijało się w oparciu o rolnictwo oraz handel, przyciągając osadników z odległych obszarów. Różnicowaniu się struktury demograficznej Suboticy sprzyjały również czynniki polityczne i historyczne [informacje o nich znaleźć można w pozycjach: Eberhardt 2005; Felczak 1983; Felczak, Wasilewski 1985; Mađar 2004; Sabo 2002]. Badania archeologiczne potwierdziły ślady obecności Scytów, Daków, Sarmatów, Gotów, Alanów, Hunów, Awarów, Słowian (w VI i VII w.). W IX w. na tereny te przybyli Madziarzy. W średniowieczu Subotica pozostawała w rękach feudałów węgierskich. $Z$ tego okresu, z roku $1391 \mathrm{r}$, pochodzi też pierwsza wzmianka o mieście. Po bitwie pod Mohaczem, w latach 1526-1527 Subotica została stolicą słowiańskiego państwa pod wodzą samozwańczego cara Jovana Czarnego, by następnie przejść pod władzę turecką do $1686 \mathrm{r}$. W drugiej połowie XVII w., w związku z przesiedleniami ludności węgierskiej na tereny północne Niziny Panońskiej, na obszar nowo utworzonego Pogranicza Wojskowego stopniowo napływała ludność słowiańska, w tym Buniewcy (największa fala w 1687 r.) oraz Serbowie (ostatnia dekada XVII w.). Te dwa narody słowiańskie wraz z Węgrami, którzy po zniesieniu jarzma tureckiego powracali do Baczki, do dziś pozostają obecne w życiu społecznym, kulturalnym i politycznym Suboticy. Chęć uzyskania przywilejów i miana wolnego miasta królewskiego w ramach Monarchii Habsburskiej skłoniła władze miasta w XVIII w. do wydania pozwolenia na osiedlanie się także przedstawicieli innych narodowości, w tym, od 1775 r., Żydów, którzy mieli zagwarantować rozwój rzemiosła w rolniczej dotychczas Suboticy [http://elmundosefarad.wikidot.com/kosmopolitizam-i-nacionalna-samosvest-jevreji-u-botici]. Rozwoju miasta jako ośrodka przemysłowego i kulturalnego o zróżnicowanej strukturze etnicznej nie przerwała I wojna światowa oraz będące jej następstwem włączenie w 1918 r. Suboticy do Królestwa Serbów, Chorwatów i Słoweńców (SHS). Istotne zmiany przyniosła II wojna światowa, podczas której miasto okupowane było przez Węgrów, a ludność żydowska została eksterminowana. Po 1945 r. Subotica znalazła się w Jugosławii (od 1963 r. - Socjalistycznej Federacyjnej Republice Jugosławii - SFRJ), 
której komunistyczne władze negowały istnienie ludności buniewskiej uznanej w 1948 r. za chorwacką [http://bunjevci.com/site/dokumenta/dekret-o-hrvatstvu-bunjevaca]. W 1961 r. przyznano status narodu Jugosłowianom, zaś w 1971 r., Muzułmanom - tj. wyznawcom islamu zamieszkującym SFRJ. W efekcie wydarzeń i zmian politycznych lat 90 . XX w., do jednej grupy narodowej odnosi się kilka pojęć, czego przykładem są Boszniacy i Muzułmanie. Na skutek decyzji z 1948 r. część Buniewców uważa się za Chorwatów, podczas gdy inni twierdzą, że stanowią odrębny naród, na co zezwala im serbskie prawo [Ustav Republike Srbije 1990; Zakon o... 2002]. Tę skomplikowaną sytuację potwierdzają statystyki ze spisu ludności z 2002 r., według którego w liczącej 99981 mieszkańców Suboticy Węgrzy stanowili 35\%, Serbowie 26\%, Buniewcy 11\%, Chorwaci 10\%, Jugosłowianie 7\%, Czarnogórcy 2\%, Romowie 1\%, zaś pozostali, do których zaliczyć należy Macedończyków, Muzułmanów, Albańczyków, Niemców, Słowaków, Rusinów, Słoweńców, Boszniaków, Rosjan, Bułgarów, Żydów i innych - 8\% obywateli. Obecność tych narodów jest widoczna w przestrzeni miasta w postaci pomników, świątyń (katolickie, prawosławne, protestanckie, muzułmańska, judaistyczna), wydarzeń kulturalnych, czy wreszcie szyldów oraz nazw ulic, zapisanych w języku serbskim cyrylicą, węgierskim oraz chorwackim łacinką ${ }^{1}$.

\section{Metodologia badania}

Nie tylko zapis hodonimów w trzech językach urzędowych miasta, lecz przede wszystkim osoby i wydarzenia upamiętnione w członie odróżniającym hodonimów mogą świadczyć o wielokulturowości miasta. Celem zweryfikowania tego przypuszczenia zdecydowano się na analizę nazw ulic trzech centralnych dzielnic Suboticy - Centar I, Centar II oraz Centar III z okresu międzywojnia, jugosłowiańskiego oraz z $2011 \mathrm{r}$. Ograniczenie się do zaprezentowania obszaru ścisłego centrum wynika z następujących czynników: we wszystkich rozpatrywanych okresach obszary te pozostawały $\mathrm{w}$ granicach administracyjnych miasta, co umożliwia ich porównanie, ponadto, zgodnie z teorią falową Schmidta, badane zjawisko powinno być najbardziej czytelne właśnie w tych dzielnicach, które stanowią historyczne jądro miasta² ${ }^{2}$ Zestawiono nazwy ulic z okresów, w których Subotica pozostawała w rękach Serbów, rezygnując tym samym z tych, w których należała do Węgier (tj. sprzed 1918 r. oraz z czasów II wojny światowej), co stworzyło możliwość komparacji przeobrażeń w granicach państw słowiańskich,

${ }^{1}$ Język chorwacki uznany jest za język Chorwatów i Buniewców, gdyż buniewski nie jest ustandaryzowany.

2 Zestawienie nazw ulic centrum miasta od 1868 do 1962/1963, zarówno serbskich, jak i węgierskich, opublikowane zostało przez Vujkovicia Lamicia [2012: 54-70] z komentarzem historycznym, jednak bez interpretacji zebranego materiału. 
której dokonano na podstawie map z 1928 r., 1968 r. oraz inwentaryzacji terenowej przeprowadzonej we wrześniu 2011 r., odnosząc się wyłącznie do nazw zapisanych w języku serbskim. W każdym z okresów wyodrębniono około stu jednostek, których członami określanymi (utożsamiającymi) są: ulica, put (srb. droga), trg (srb. plac), park, aleja ${ }^{3}$. Różnice w liczbie nazw ulic oraz placów i parków wynikają m.in. ze zmian w planie miasta (np. po II wojnie światowej, kiedy to przebudowano zbombardowane w czasie wojny koszary, likwidując tym samym część istniejących ulic, czy utworzono reprezentacyjną aleję Maršala Tita) oraz wydzielaniu nowych w obrębie już istniejących (np. wyodrębniono Trg svete Terezije $\mathrm{z}$ fragmentu Trg žrtava fašizma czy Trg franjevaca w obrębie Trg cara Jovana Nenada). Analizie poddano człon określający (odróżniający), którego semantyka świadczyć może o związkach danego ciągu komunikacyjnego lub elementów powierzchniowych (place, parki) z określoną grupą narodową, tym bardziej, że większość urbotoponimów subotickich ma charakter upamiętniający. Przedmiotem zainteresowania nie były więc typy strukturalne ${ }^{4}$, a semantyczne.

Odnosząc się do typów semantycznych zaproponowanych przez Handke [1970: 60-61], dokonano przyporządkowania kulturowego do hodonimów pochodzących od nazw własnych (osobowych, etniczno-geograficznych, miejscowości, topograficznych), od nazw pospolitych (związanych z faktami historycznymi). Podążając za słowami jugosłowiańskiego noblisty Ivo Andrića: „Po naszej śmierci możecie badać i to, czym byliśmy, i to, o czym pisaliśmy, lecz za naszego życia - tylko to drugie" [Andrić 1986: 124], na podstawie przygotowanych spisów nazw ulic, placów i parków dokonano przyporządkowania członu określającego, głównie o charakterze upamiętniającym, do następujących grup kulturowych: buniewskiej, chorwackiej, jugosłowiańskiej, macedońskiej, rosyjskiej, serbskiej, słoweńskiej, węgierskiej i innych oraz nazwy bez odniesienia kulturowego. Zdecydowano się na stosowanie szerszego pojęcia odniesienia kulturowego, a nie węższego - narodowego, co umożliwiło rozpatrywanie, obok nazwisk patronów ulic, także nazwy odnoszące się do jednostek geograficznych i wydarzeń historycznych. Przy przypisywaniu nazw do określonych kultur nazwy geograficzne odnoszono do współczesnego podziału administracyjnego (w sytuacji, gdy nazwa odnosi się do obiektu leżącego w granicach kilku państw, jak np. kraina Srem będąca w granicach Serbii i Chorwacji, nazwę traktowano jako wielokulturową). W przypadku nazw osobowych: za Buniewców bezwyjątkowo uznano Chorwatów z Baczki działających do II wojny światowej, zaś po II wojnie światowej

${ }^{3}$ Pełną listę członów utożsamiających typowych dla Wojwodiny przygotował Marković w pracy poświęconej toponimii gminy Plandište [Marković 1996: 86-87].

${ }^{4}$ Pośród rozpatrywanych nazw dominowały te z derywacją fleksyjną w dopełniaczu (np. ulica Henrika Sijenkijevića), bez kreacji formalnojęzykowej - przymiotnikowe (np. ulica Uska), zaś na planie z 1928 r. - z formacją sufiksalną poprzez formant -eva (np. ulica Trumbićeva), który w znacznej mierze utrudnia identyfikację patrona ulicy. 
- przypisania dokonywano na podstawie studiów biografii do Buniewców lub Chorwatów. Za Jugosłowian uznano osoby działające w czasach komunistycznych oraz uznane za bohaterów narodowych Jugosławii. Do osób, których działalność pozostawała na rozdrożu dwóch lub więcej kultur, zastosowano kategorię wielokulturowości. Przyporządkowania dokonywano w oparciu o studia literatury [Bogdanov 1974; Sekulić 1989] oraz artykułów, stron i forów internetowych [m.in. Kuntić, strony internetowe podane w bibliografii końcowej z datą dostępu 30.09.2012], co okazało się szczególnie przydatne podczas analizy nazw z okresu międzywojnia. Odnoszenie się do powszechnie dostępnych danych, a nie archiwaliów, było zabiegiem celowym. Sposób ten umożliwia ocenę czytelności wielokulturowości miasta nie przez specjalistów, a przez odwiedzających lub mieszkańców miasta niemających wykształcenia historycznego, a dysponujących podstawowymi narzędziami, jak Internet czy encyklopedia.

\section{Plateonimy i agoronimy Suboticy w okresie międzywojennym}

Dane ze spisów ludności z roku 1921 oraz 1931 nie przedstawiały zróżnicowania narodowościowego, a jedynie wyznaniowe i językowe. Według danych z 1931 r. 84\% mieszkańców Suboticy była wyznania katolickiego (byli to głównie Węgrzy, Buniewcy, Chorwaci), 10\% - prawosławnego (Serbowie, Czarnogórcy i inni), zaś pozostałe $6 \%$ stanowili m.in. żydzi, protestanci. Język serbski oraz chorwacki i buniewski był ojczystym dla 54\% mieszkańców miasta, węgierski $41 \%{ }^{5}$, zaś niemiecki - 3\%. W okresie tym na analizowanym obszarze wyróżniono 102 ulice, place i parki, z czego 6 nazw pozostało niejasnych, zaś 15 nie miało odniesienia kulturowego ${ }^{6}$. Jak wskazuje rys. 1, dominowały nazwy odnoszące się do kultury serbskiej. Były to hodonimy upamiętniające rodzinę królewską (np. kralja Aleksandra, prestolonaslednika Petra), generałów oraz innych wojskowych uczestniczących w wyzwoleniu miasta w 1918 r. (Krupeževićeva), a także wybitnych twórców (Zmaj Jovina, Karadžićeva). Nazwy te otrzymały najważniejsze szlaki komunikacyjne oraz większość ulic w reprezentacyjnej dzielnicy Centar I, wraz z tymi przylegającymi do stacji kolejowej. Obok nich plasują się urbotoponimy nawiązujące do Chorwatów (w liczbie 18, np. Štrosmajerova, Zajčeva) oraz Buniewców (13, w tym Albina, Paje Kujundžića), szczególnie w dzielnicach Centar II oraz Centar III. W sumie nazwy odnoszące się do tych trzech kultur stanowią $62 \%$ wszystkich. Zaledwie 2 nazwy ulic wiążą się z kulturą węgierską, przy czym są to ulice pozostające na północnych rubieżach

5 Językiem węgierskim posługiwała się również zasymilowana ludność żydowska.

${ }^{6}$ Ze względu na fakt, iż w każdym analizowanym okresie liczba zinwentaryzowanych nazw ulic, placów i parków oscyluje około stu, zdecydowano się na podawanie wartości bezwzględnych, nie zaś procentowych. 
dzielnic Centar I i Centar II. Świadczy to o chęci wymazania przez władze SHS śladów poprzedniej - węgierskiej. Pozostałe hodonimy wykazują związek z kulturami: rosyjską (Petrogradska, Tolstojeva), polską (Sienkievićeva), słoweńską (wyłącznie poprzez nazwy geograficzne), macedońską oraz innymi.

Plateonimy oraz agoronimy z okresu międzywojennego oddają obraz Suboticy jako miasta słowiańskiego, przysłaniając pierwiastek węgierski, a tym samym fałszując rzeczywiste zróżnicowanie kulturowe miasta.

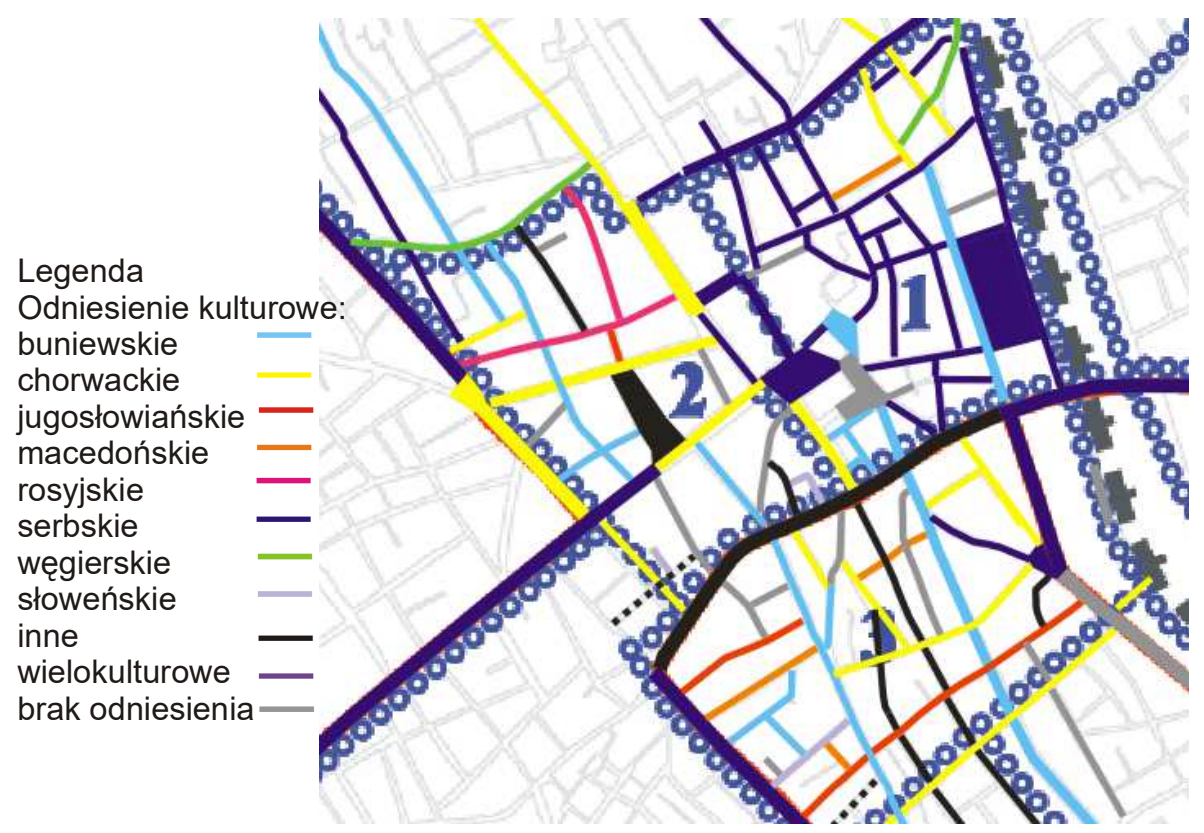

Rys. 1. Odniesienia kulturowe plateonimów oraz agoronimów Suboticy w roku 1928 1 - Centar I, 2 - Centar II, 3 - Centar III

Źródło: opracowanie własne, 2012, na podkładzie wykonanym przez JP Zavod za Urbanizam Grada Subotice

\section{Plateonimy i agoronimy Suboticy po II wojnie światowej}

Po II wojnie światowej komunistyczne władze Jugosławii zanegowały istnienie narodu buniewskiego, a usankcjonowano bytność Jugosłowian i Muzułmanów. Struktura narodowościowa Suboticy liczącej, według danych ze spisu ludności z 1971 r., 88813 mieszkańców przedstawiała się następująco: większość stanowili Węgrzy (49\%), Chorwaci, do których zaliczono też Buniewców - 32\%, Serbowie - 13\%, zaś Jugosłowianie zaledwie 3\%, a inne narody $-3 \%$. 
Na planie miasta z 1968 r. oznaczono 101 ulic i placów, z czego 93 mają odniesienie kulturowe, zaś 1 pozostała niejasna. Relacje między urbotoponimami a ich odniesieniem kulturowym przedstawia rys. 2 .

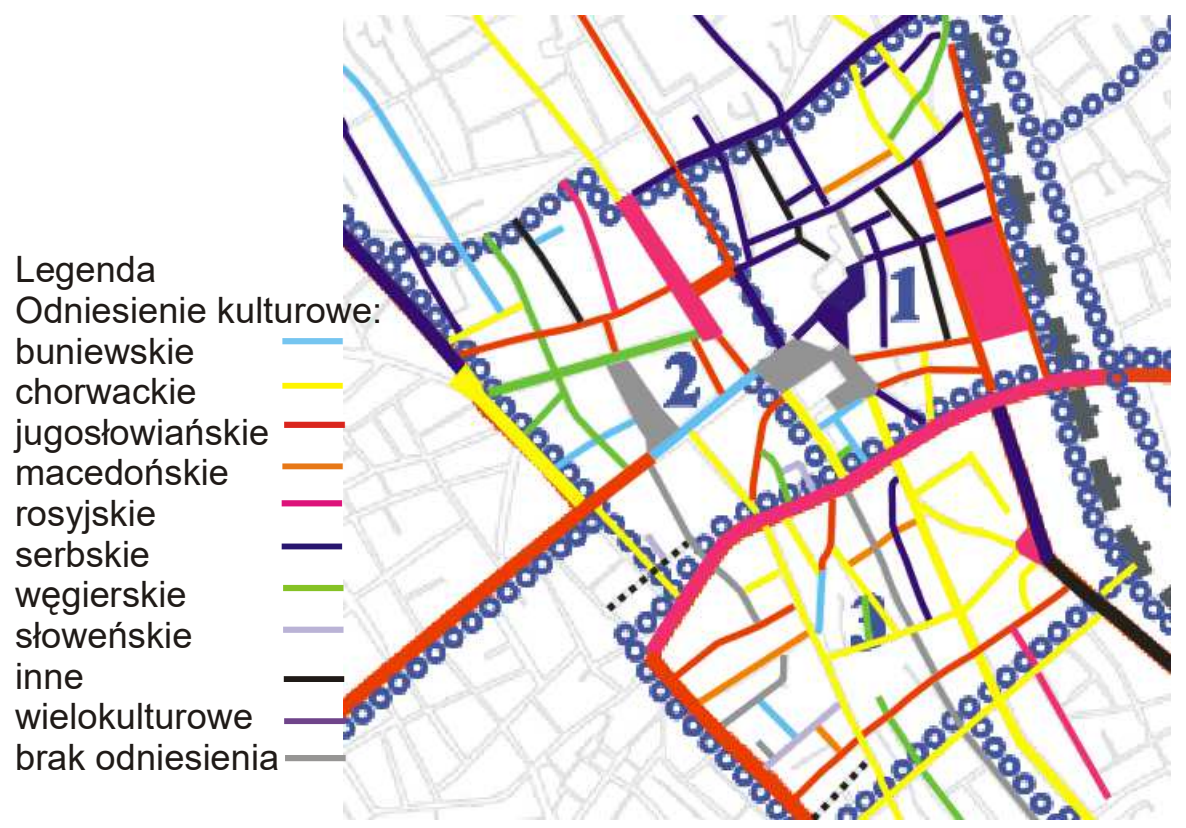

Rys. 2. Odniesienia kulturowe plateonimów oraz agoronimów Suboticy w roku 1968 1 - Centar I, 2 - Centar II, 3 - Centar III

Źródło: opracowanie własne, 2012, na podkładzie wykonanym przez JP Zavod za Urbanizam Grada Subotice

W porównaniu z okresem międzywojennym, zaobserwować można zmniejszenie udziału odniesień do kultury serbskiej (do 19) oraz buniewskiej (do 8) na rzecz kultury chorwackiej (do 21), węgierskiej (do 7), rosyjskiej (do 6), a także pojawienie się nazw nawiązujących do kultury jugosłowiańskiej (16). W nazewnictwie miejskim głównych dróg oraz reprezentacyjnych ulic i placów pojawiły się nazwy upamiętniające działaczy socjalizmu oraz wydarzenia istotne dla rozwoju komunizmu (Engelsova, Čapajeva, Marksov put, Oktobarske revolucije, Lenjinov park, Jugoslovenske narodne armije). W południowej części analizowanego obszaru, w dzielnicy Centar III, dominowały nazwy odnoszące się do kultury chorwackiej (np. braće Radića, Matije Gupca, Mirka Bogovića). Hodonimy wykazujące związek z kulturą węgierską przypisano głównie ulicom położonym w dzielnicy Centar II (np. Šandora Petefija, Ištvana Ivanjija, Atile Jožefa), tradycyjnie zamieszkałą przez Węgrów. Interesująco przedstawia się sytuacja z nazwami nawiązującymi do kultury rosyjskiej, gdzie, oprócz wspomnianych 
komunistycznych, obecne były nazwy pamiątkowe, wskazujące na wybitnych przedstawicieli kultury (Tolstojeva, Puškinov trg, Maksima Gorkog).

Struktura odniesień kulturowych urbotoponimów Suboticy po 1945 r., mimo wprowadzenia hodonimów upamiętniających wydarzenia oraz osoby działające na rzecz komunizmu, wykazywała większe zróżnicowanie niż w międzywojniu, oddając zróżnicowanie demograficzne tego okresu. Należy zauważyć, że wraz z zanegowaniem narodu buniewskiego zmniejszyła się liczba urbotoponimów związanych z tą grupą, a wzrosła liczba nazw odnoszących się do kultury chorwackiej. Zmniejszyła się też liczba nazw związanych z kulturą serbską na rzecz kultury jugosłowiańskiej. Pojawiły się również ulice nawiązujących do społeczności węgierskiej. Zmiany nazw ulic dotyczyły przede wszystkim tych położonych w reprezentacyjnym centrum oraz głównych szlaków komunikacyjnych.

\section{Plateonimy i agoronimy Suboticy - stan obecny}

Analizy aktualnych hodonimów centralnych dzielnic Suboticy dokonano, stosując metodę inwentaryzacji urbanistycznej, zaś jej wyniki przyrównano do danych ze spisu ludności z 2002 r. W 2011 r., kiedy przeprowadzano badania, trwał spis powszechny, jednakże w momencie przygotowywania artykułu jego wyniki nie były jeszcze opublikowane. Natomiast szczegółowe dane z 2002 r. umożliwiają prześledzenie zróżnicowania narodowościowego w poszczególnych dzielnicach miasta. Centar I, tradycyjnie uważany za dzielnicę serbską, zamieszkują: Serbowie (40\%), Węgrzy (25\%), Buniewcy i Jugosłowianie (po 7\%), Chorwaci $(6 \%)$ oraz inne narodowości. Na uwagę zasługuje fakt, że procentowy udział ludności serbskiej i węgierskiej w tej dzielnicy jest odwrotny niż średni dla miasta (odpowiednio 26\% i 34\%). W strefie Centar II, którą od średniowiecza zamieszkiwała głównie ludność węgierska, Węgrzy stanowią 38\%, Serbowie $-25 \%$, Chorwaci $-9 \%$, Buniewcy $-7 \%$, Jugosłowianie $-7 \%$. Struktura ta w nieznacznym stopniu odbiega od średniej dla Suboticy. Natomiast w dzielnicy Centar III większość stanowią Serbowie (37\%), Węgrzy - 25\%, Chorwaci - 11\%, Buniewcy $-9 \%$, a Jugosłowianie $-5 \%$. Struktura tego obszaru zbliżona jest więc do Centar I, z tym, że większy jest udział ludności chorwackiej oraz buniewskiej. Jak zobaczyć można na rys. 3., równie zróżnicowane są odniesienia kulturowe nazw ulic i placów tych jednostek administracyjnych.

Podczas inwentaryzacji urbanistycznej zarejestrowano 102 urbotoponimy, z czego jeden pozostaje niejasny. Liczba hodonimów związanych z kulturą chorwacką (21), w porównaniu do roku 1968, nie uległa zmianie. Zwiększyła się liczba odniesień do kultury serbskiej (23), buniewskiej (9), węgierskiej (12), mniej jest natomiast tych, które kojarzone są z kulturą rosyjską (4), słoweńską (3), a przede wszystkim - jugosłowiańską (8). Zaobserwować można także, iż 


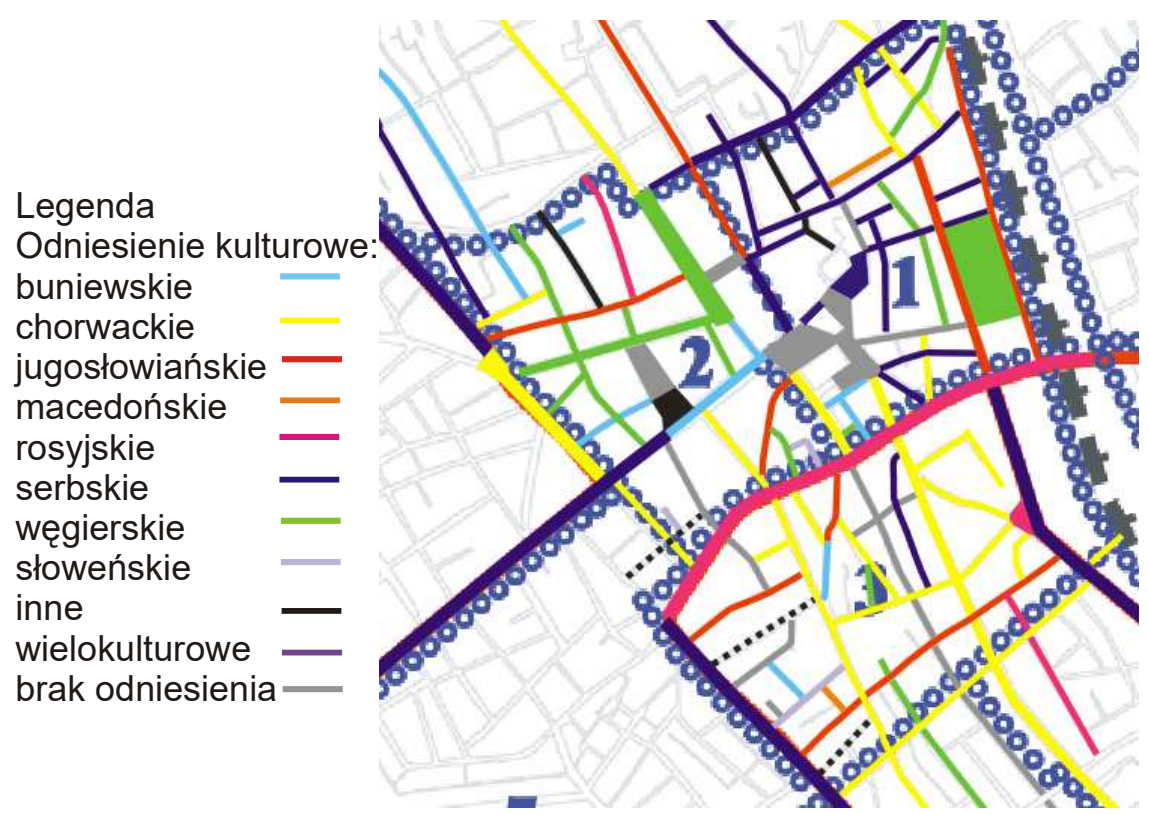

Rys. 3. Odniesienia kulturowe plateonimów oraz agoronimów Suboticy w roku 2011 1 - Centar I, 2 - Centar II, 3 - Centar III

Źródło: opracowanie własne, 2012, na podkładzie wykonanym przez JP Zavod za Urbanizm Grada Subotice

w przypadku nazw odnoszących się do kultury rosyjskiej zmieniono tylko nawiązujące do polityków oraz wydarzeń historycznych, pozostawiając urbotoponimy upamiętniające wybitnych twórców kultury (Tolstojeva, Puškinov trg, Maksima Gor$k o g$ ), a w jednym przypadku zastępując nazwisko komunisty nazwiskiem literata (Ćapajeva $>$ Šolohova). Z nazewnictwa miejskiego bezwarunkowo usunięto nazwiska komunistów (Engelsova $>$ Matije Korvina, Marksov put $>$ Senćanski put, Lenjinov park>park Ferenca Rajhla), a pozostawiono w większości nazwy ulic noszące imię lokalnych działaczy (np. Maršala Tita, Đure Đakovića, Sonje Marinković). W efekcie w dzielnicy Centar I, zamieszkałej głównie przez Serbów, dominują nazwy związane z kulturą serbską, choć pojawiły się też nawiązujące do kultury węgierskiej - dotyczy to położonego przy stacji kolejowej parku Ferenca Rajhla oraz reprezentacyjnej ulicy Matije Korvina. W strefie Centar II, w której większość stanowią Węgrzy, przeważa liczba urbotoponimów odnoszących się do kultury węgierskiej. W Centar III natomiast, gdzie udział ludności buniewskiej oraz chorwackiej jest największy spośród analizowanych dzielnic, liczba nazw ulic i placów odnoszących się do kultury serbskiej bądź węgierskiej jest znikoma. W centrum miasta, wokół ratusza oraz prowadzącej do niego ze stacji kolejowej ulicy, urbotoponimy nie wykazują związku z wyróżnionymi kulturami (Korzo, Trg slobode, Trg republike). 


\section{Wnioski}

Metoda przestrzennej analizy urbotoponimów jako znaków potwierdzających wielokulturowość miasta napotyka pewne trudności, jak niemożliwość przypisania danej nazwy do konkretnej kultury. Problem ten jednak można pokonać, stosując kategorię wielokulturowości. Kolejną kwestią jest niejasność niektórych nazw (w przypadku Suboticy - tych z formantem -eva).

Decydując się na stosowanie tej metody, należy więc dokonać przemyślanego wyboru kategorii, które mogą być zastosowane na badanym obszarze. Metoda ta umożliwia analizę miast w układzie diachronicznym i synchronicznym jednakże w państwach wielonarodowych może wymagać stosowania różnych kategorii dla poszczególnych regionów lub, w ujęciu diachronicznym, dla poszczególnych okresów historycznych.

Analizując plateonimy i agoronimy w centralnych dzielnicach Suboticy, wykazano, że odniesienie kulturowe ukryte w nazwach ulic stanowią nie tylko zapis struktury narodowościowej i etnicznej miasta, lecz także aktualnych wydarzeń politycznych. Należy zauważyć, że mimo obecności ludności żydowskiej w mieście (co czytelne jest i dziś w pomnikach, poprzez synagogę czy budynek gminy żydowskiej) nazwy ulic jej nie odzwierciedlają (Rys. 4). Przypuszczać można, iż jest to wynikiem asymilacji wyznawców judaizmu, którzy w Suboticy mają poczucie wspólnoty wiary, nie zaś narodowej, czując się przy tym Węgrami czy Serbami.

Inne zjawisko, które zaobserwowano, podsumować można słowami Ivo Andricia: „Wojna, nawet najdłuższa, jedynie przetrząsa sprawy, z powodu których wybuchła, a ich rozwiązanie zostawia czasom, co następują po zawarciu pokoju" [Andrić 1986: 56]. Po I wojnie światowej, kiedy Subotica po raz pierwszy (nie licząc epizodu z lat 1526-1527) znalazła się w granicach państwa słowiańskiego, blisko 1/3 stanowiły nazwy ulic związane z kulturą serbską, zaś związki z kulturą węgierską zostały zanegowane. Ta stosunkowa jednorodność nazewnictwa miejskiego była jednak nienaturalnym tworem w przestrzeni miasta, które od początków swojego istnienia było wielokulturowe. Kolejny chaos zapanował po II wojnie światowej, kiedy to zmniejszyła się liczba nazw ulic odnoszących się do Buniewców, dla których Subotica pozostaje nieoficjalną stolicą. Jednocześnie urbotoponimy związane z kulturą jugosłowiańską uplasowały się tuż za tymi związanymi z kulturą serbską i chorwacką. Mapa przedstawiająca ulice i place miasta jako odnoszące się do wyodrębnionych kultur, przypomina mozaikę, która, w tym przypadku, nie świadczy o bezładzie, a stanowi odzwierciedlenie struktury narodowościowej oraz historii miasta, jest dla niego naturalną.

Podsumowując, zastosowana metoda inwentaryzacji urbanistycznej pozwala na badanie miasta wielokulturowego, oddając jego złożoność zarówno w diachronii, jak i synchronii. Może ona zostać poszerzona (np. o analizę statystyczną długości traktów itp.), umożliwiając pogłębienie wiedzy historycznej i geograficznej o badanym obszarze. 


\begin{tabular}{|l|c|c|c|}
\hline \multirow{2}{*}{$\begin{array}{c}\text { Odniesienie } \\
\text { kulturowe }\end{array}$} & $\mathbf{1 9 2 8}$ & $\mathbf{1 9 6 8}$ & $\mathbf{2 0 1 1}$ \\
\cline { 2 - 4 } & 13 & 8 & 9 \\
\hline Buniewskie & 18 & 21 & 21 \\
\hline Chorwackie & 0 & 16 & 8 \\
\hline Jugosłowiańskie & 1 & 2 & 2 \\
\hline Macedońskie & 2 & 6 & 4 \\
\hline Rosyjskie & 32 & 19 & 23 \\
\hline Serbskie & 3 & 5 & 3 \\
\hline Słoweńskie & 2 & 7 & 3 \\
\hline Węgierskie & 7 & 5 & 4 \\
\hline Inne & 3 & 3 & 12 \\
\hline Wielokulturowe & 15 & 8 & 1 \\
\hline Brak odniesienia & 6 & 1 & $\mathbf{1 0 2}$ \\
\hline Niezidentyfikowane & $\mathbf{1 0 2}$ & $\mathbf{1 0 1}$ & 3 \\
\hline Suma & & & \\
\hline
\end{tabular}

Rys. 4. Zestawienie zinwentaryzowanych nazw według wyodrębnionych kategorii.

Źródło: opracowanie własne, 2012

\section{Bibliografia}

Andrić Ivo, 1986, Przydrożne znaki, Warszawa.

Balowski Mieczysław, 2010, Zmiana funkcji nazw ulic i placów (od funkcji orientacyjnej do funkcji symboliczno-lokalizacyjnej), [w:] Irena Sarnowska-Giefing (red.), Miasto w perspektywie onomastyki i historii, Poznań, 281-298.

Bogdanov Nada (red.), 1974, Leksikon JLZ, Zagreb.

Eberhardt Piotr, 2005, Przemiany demograficzno-etniczne na obszarze Jugostawii $w$ XX wieku, Lublin.

Felczak Wacław, 1983, Historia Wegier, Wrocław.

Felczak Wacław, Wasilewski Tadeusz, 1985, Historia Jugosławii, Wrocław.

Handke Kwiryna, 1970, Semantyczne i strukturalne typy nazw ulic Warszawy, Wrocław.

Handke Kwiryna, 2010, Konstrukcja i dekonstrukcja systemu nazewnictwa miejskiego w polskich miastach, [w:] Irena Sarnowska-Giefing (red.), Miasto w perspektywie onomastyki i historii, Poznań, 357-372.

Kalman Kuntić, Uticaj političkih promena na položaj i nacionalno izjašnjavanje Hrvata-Bunjevaca u Bačkoj tokom 20. veka, http://www.cpi.hr/download/links/hr/7074.pdf [dostęp 30.09.2012].

Laćević Milica, 1984, Prilog proučavanju naše hodonimije, „Onomatološki prilozi““ V, 217-228.

Mađar Laslo, 2004, Ilustrovana istorija Subotice, Subotica.

Marković Željko, 1996, Toponimija opštine Plandište, „Prilozi proučavanju jezika“ 27, 79-136.

Popis stanovništva, 1921.

Popis stanovništva, 1931.

Popis stanovništva, 1971.

Popis stanovništva, 2002. 
Sabo Žombor, 2002, Stepski grad, Subotica.

Sarnowska-Giefing Irena (red.), 2010, Miasto w perspektywie onomastyki i historii, Poznań.

Sekulić Ante, 1989, Bački Bunjevci i Šokci, Zagreb.

Ustav Republike Srbije, 1990, Beograd.

Vujković Lamić Ljudevit, 2012, Prilog o subotičkim ulicama i njihovim nazivima, „EX PANNONIA“, broj 15-16, 54-70.

Zakon o zaštiti prava i sloboda nacionalnih manjina, 2002, Beograd.

http://bunjevci.com/novine/pdf/bunjevacke/2009_53.pdf [dostęp 30.09.2012].

http://bunjevci.com/site/dokumenta/dekret-o-hrvatstvu-bunjevaca/ [dostęp 5.10.2012].

http://elmundosefarad.wikidot.com/kosmopolitizam-i-nacionalna-samosvest-jevreji-u-subotici [dostęp 23.09.2012].

$\mathrm{http}$ ://forum.axishistory.com/viewtopic.php?f=52\&t=52104\&start=45 [dostęp 30.09.2012].

http://suistorija.wordpress.com/2012/03/03/subotica-1933-godine-po-izvjestaju-gradskog-kulturno-socijalnog-odjeljenja/ [dostęp 30.09.2012].

http://www.croatia.ch/tjedan/050613b.php [dostęp 30.09.2012].

http://www.gradsubotica.co.rs [dostęp 30.09.2012].

http://www.skyscrapercity.com [dostęp 30.09.2012].

Armina Muszyńska

\title{
Hodonyms of Subotica downtown as an evidence of city's multiculturalism
}

\author{
(Summary)
}

Hodonyms function as symbols and convey information about relations between the inhabitants of the city. Considered as signs, they stigmatize space and, by references to different cultures, they reflect the demographic structure, in particular, the ethnic one. The article attempts to classify names of streets, squares and parks according to their references to the different cultures. The analysis was conducted on the example of the center of Subotica, a multicultural city in Serbia, near the border with Hungary. The next step was to present the phenomena on maps, which was done for three historical periods: the interwar, the Communist era and current state. The first two are based on maps from 1928 and 1968, and the current one is based on field research curried out in September 2011. The information obtained in this way was compared to the census results of different periods, analyzing the relationship between demographic structure and the information stored in the hodonyms. The analysis confirmed the possibility of using this method in terms of synchronic and diachronic viewpoint.

Słowa kluczowe: wielokulturowość, urbotopominy, Subotica, centrum miasta.

Key words: multiculturalism, hodonyms, Subotica, downtown. 